\title{
Model to increase foreign tourism to Michoacán
}

\section{Modelo para incrementar el turismo extranjero hacia el estado de Michoacán}

\author{
MOLINA-MARTINEZ, Rubén*† \& CHAVEZ-CHAVEZ, Amparo Guadalupe \\ Universidad Michoacana de San Nicolás de Hidalgo, Institute of Economic and Business Research, Mexico. \\ ID $1^{\text {st }}$ Author: Rubén, Molina-Martinez, / ORC ID: 0000-0002-9840-6441, Research ID Thomson: K-7424-2018, CVU \\ CONACYT ID: 14701
}

ID $1^{\text {st }}$ Coauthor: Amparo Guadalupe, Chavez-Chavez / ORC ID: 0000-0003-1992-1128

DOI: $10.35429 / J M P C .2020 .18 .6 .1 .9$

Received July 17, 2020; Accepted December 30, 2020

\begin{abstract}
This paper presents the results of an investigation about the foreign tourist affluence in the state of Michoacán. The objective of the research is to identify the main causes of the lack of growth in the tourist influx in Michoacán. A survey was carried out in which a questionnaire was applied to 380 foreign tourists who visited the state in the period of OctoberNovember 2019. A Likert scale was used and for the analysis of the results the SPSS program (Statistical Package for the Social Sciences). The obtained results showed that the low tourist competitiveness, the lack of investment in the tourist infrastructure and the little diversification in the tourist offer have prevented the increase of the tourist affluence in the state. Finally, a Comprehensive Tourism Planning Model was proposed as a solution to the detected problem.
\end{abstract}

International tourism, Tourism sector, Tourism competitiveness, Tourism infrastructure, Tourism offer

\begin{abstract}
Resumen
Este artículo presenta los resultados de una investigación que trata sobre la afluencia turística extranjera en el estado de Michoacán. El objetivo de la investigación es identificar las principales causas de la falta de crecimiento en la afluencia turística en Michoacán. Se realizó una encuesta en la que se aplicó un cuestionario a 380 turistas extranjeros que visitaron el estado en el periodo de octubrenoviembre de 2019. Se utilizó una escala tipo Likert y para el análisis de los resultados el programa SPSS (Statistical Package for the Social Sciences). Los resultados obtenidos mostraron que la baja competitividad turística, la falta de inversión en la infraestructura turística y la poca diversificación en la oferta turística han impedido el incremento de la afluencia turística en el estado. Finalmente, se propuso un Modelo Integral de Planificación turística como solución al problema detectado.
\end{abstract}

Turismo internacional, Sector turístico, Competitividad turística, Infraestructura turística, Oferta turística

Citation: MOLINA-MARTINEZ, Rubén \& CHAVEZ-CHAVEZ, Amparo Guadalupe. Model to increase foreign tourism to Michoacán. Journal of Microfinance Planning and Control. 2020. 6-18:1-9.

\footnotetext{
* Correspondence to the Author (Email: ruben.molinam@gmail.com)

$\uparrow$ Researcher contributing as first author.
} 


\section{Introduction}

World tourism is a key engine for socioeconomic progress in countries, it is one of the main players in international business and represents one of the main sources of income for various developing countries. Furthermore, tourism is also one of the main sources of employment worldwide. According to the World Tourism Organization (2018), one in every 11 jobs in the world is related to tourism. In Mexico, the tourism sector generates a more accelerated economic impact compared to other productive branches. The geographical location, connectivity, the extensive tourism inventory system and the ability to offer quality tourism services position it as a country with a strong comparative advantage, however, its participation in the world market has decreased.

One of the states of the country that has lost presence in the global competition in this sector is the state of Michoacán. Michoacán has the potential to offer quality tourist services due to its diversity in both ecological and cultural tourist attractions, however, it has presented a stagnation in the tourist influx in recent years. The objective of this research is to identify the factors that have caused that there is no increase in the tourist influx in the State. It is considered important to put the study focus on the tourist influx of foreigners, because they represent an important source of income to the country, generating greater economic income compared to national tourism. The research starts from a diagnosis of the current situation of the tourism sector at the world, national and state level. The hypothesis proposed for this research is that the influx of foreign tourists (dependent variable) to Michoacán can be increased by improving tourism competitiveness (independent variable 1), increasing investment in tourism infrastructure (independent variable 2) and diversifying the tourism offer ( independent variable 3 ). In the field work, the universe and the sample were defined, the instruments were selected for data collection and processing, and finally the results were presented and analyzed. For this research, a questionnaire was applied to 380 foreign tourists who visited Michoacán in the period October-November 2019 and the SPSS and Excel programs were used to process the data obtained.
The last part of this research is made up of the proposed solution to the identified problem, which consists of the application and control of a Comprehensive Tourism Planning Model to develop the sector and increase the tourist influx in the state of Michoacán.

\section{Literary Review}

The World Tourism Organization (1998) defines tourism as the activities carried out by people during their trips and stays in places other than their usual environment, for a consecutive period of less than one year, for leisure purposes, and other reasons not related to the exercise of a remunerated activity in the place visited. Likewise, it declares that a tourist is defined as a visitor who spends the night in a means of collective or private accommodation in the place visited for at least one night. Next, the main models that give the theoretical support to this research are presented. The first model is the one proposed by Raymundo Cuervo (1967), where he proposes an analysis of tourism using systems theory, arguing that any change in the environment directly affects the tourism system. His proposal was published in "Tourism as a means of human communication", published in 1997 by the Government Tourism in Mexico.

Cuervo coordinated the study and analysis of the research presented, by which, for the first time, the concept of a system applied to tourism. Cuervo (1967) is based on the assumption that tourism is a group whose function is communication, he argues that tourism is a communication system capable of transmitting positive and useful information for the promotion of world peace, but it can also be negative and affect the harmony of human relationships. Seen from this perspective, the tourism system must always function, or always be maintained, as a positive communication operator (Panosso \& Lohmann, 2012).

Another systemic approach is the Leiper (1990), which proposed a model of a tourist system composed of five elements, three geographical elements: the region of origin of the traveler (the origin or the usual environment of consciousness of the traveler), a region of transit that intercommunicates the origin with the destination, and the region of the tourist destination. 
The other two elements are the tourist and the tourism and travel industry. All these elements are impacted by the human environment, the sociocultural, economic, technological, physical, political and legal, and in turn, the elements impact these environments when the tourist travels their route starting from the origin heading to the destination through the region of transit. In 1999, UNWTO provided planning models for municipal and local levels. in which it deepens the strategic planning process applied to tourism in its aspects of land use planning, tourism modalities (urban tourism, ecotourism), and the creation and management of tourism products. Although this orientation has been aimed at public organizations responsible for tourism planning in developing countries, the proposal made by experts and academics from other instances and private and social institutions is not far from the general methodological elements proposed by said organization (Osorio , 2006).

On the other hand, the integrated model of competitiveness of a tourist destination proposed by Dwyer \& Kim (2003), which integrates elements such as; created resources such as tourism infrastructure, recreational activities, and commerce; hereditary and natural resources such as historical and social heritage; and resources and factors such as general infrastructure, quality of services, accessibility and hospitality. In turn, this model considers the environment which it encompasses; conditions for development such as the geographical situation, the competitive environment, the macroeconomic environment, security and price competitiveness; politics and management as management of organizations, advertising and marketing, development of Human Resources; and demand conditions such as tourist preferences and their perception of the tourist destination. Finally, the interaction of these elements results in tourist competitiveness.

\section{Methodology}

This section defines the universe and the sample, as well as the instrument for data collection and processing. The universe is made up of foreign tourists who visit the main tourist destinations in Michoacán. As a reference, foreign tourists who visited the State in 1122016 are taken into account, which were 33,931 (SECTUR, 2018). The main tourist destinations in the state are Morelia, Pátzcuaro and the coastal area.
For this research, the sample is taken considering the size of the population, the level of confidence and the margin of error, applying the following formula (Vivanco, 2005):

$$
n=\frac{Z_{\propto}^{2} N p q}{e^{2}(N-1)+Z_{\alpha}^{2} N p q}
$$

Where:

$\mathrm{N}=$ Universe $=33,931$ tourists

$\mathrm{n}=$ sample size

$\mathrm{Z}=$ confidence level $=95 \%$

$\mathrm{e}=$ Error $=0.05$

$\mathrm{p}=$ proportion of the sample (probability of success) $=50 \%$

$\mathrm{q}=$ proportion of the sample (probability of failure $)=50 \%$

To perform this calculation, $\mathrm{N}$ is equal to 33,931 foreign tourists, $\mathrm{Z}$ is equal to 1.96 , which represents the $95 \%$ confidence level, with an error of 0.05 and $p$ takes the value of $50 \%$. This last percentage is due to the part of the population that is taken as the object of study, $50 \%$ is considered for $\mathrm{p}$ in the event that the study condition is met and 50\% for $\mathrm{q}$ if it is not met. The sample calculation was obtained with the following procedure:

$$
\begin{aligned}
& n=\frac{(33931)(1.96)^{2}(0.5)(0.5)}{(0.05)^{2}(33931-1)+(1.96)^{2}(0.5)(0.5)} \\
& n=\frac{(33931)(3.8416)(0.5)(0.5)}{(0.0025)(33930)+(3.8416)(0.5)(0.5)} \\
& n=\frac{32587.3324}{8482.5+0.9604} \\
& n=\frac{32587.3324}{85.7854}=380
\end{aligned}
$$

The sample is calculated with the formula previously indicated, based on a normal distribution, in addition, computer platforms were used to verify the result, such as Surveymonkey Networks and Netquest. As a result, the sample size is 380 people. 
The instrument used in this research is the Likert-type scale, because it is a tool that allows us to measure attitudes and know the degree of compliance of the respondent through the items raised, it also allows us to quantify the data to obtain more results. precise. The Likert scale named for its inventor, Rensis Likert, is a widely used measurement scale that requires respondents to indicate the degree of agreement or disagreement with each of the series of information about the stimulus objects. In general, each item on the scale has five categories of responses ranging from "strongly disagree" to "strongly agree" (Malhotra, 2004).

It is a type of additive scale that corresponds to an ordinal level of measurement; It consists of a series of items or judgments by way of statements to which the subject's reaction is requested. The stimulus (item or judgment) that is presented to the subject represents the property that the researcher is interested in measuring and the responses are requested in terms of degrees of agreement or disagreement that the subject has with the particular sentence. There are five most used response options, where each category is assigned a numerical value that will lead the subject to a total score as a result of the scores of all the items (Table 1). The final score indicates the position of the subject within the scale (Maldonado, 2007).

The Likert scale assumes that the strength and intensity of the experience is linear, therefore, it ranges from totally agree to totally disagree. In addition, it is also considered a neutral element for those people who do not agree or disagree. Through the operationalization of the variables, an instrument of 37 items was built which was applied to 380 foreign tourists who visited Morelia, Pátzcuaro and the Coastal Zone of the state of Michoacán during the period October-November 2019.

\begin{tabular}{|r|l|} 
Value & \multicolumn{1}{c|}{ Reply } \\
\hline 1 & Strongly disagree \\
\hline 2 & In disagreement \\
\hline 3 & Neither agree nor disagree \\
\hline 4 & Agree \\
\hline 5 & Totally agree \\
\hline
\end{tabular}

Table 1 Table of equivalences

Source: Own elaboration based on Likert. 1932
The applied instrument presents 37 items with 5 possible answers that correspond to the table of equivalences (table 1.1), through this coding the answers were transformed into numerical values which were used for the elaboration of the data book. Any measurement or data collection instrument must meet three essential requirements: reliability, validity and objectivity (Hernández, Fernández, \& Baptista, 1998). The instrument was validated through Cronbach's Alpha, which is a scale reliability indicator that provides a measure of the internal consistency of the items that make up the scale. For our instrument, a Cronbach's alpha coefficient of 0.790 was obtained, which indicates that the applied instrument is reliable, being considered an acceptable value. The results obtained were processed to analyze and interpret them. According to Hurtado (2000), the purpose of the analysis is to apply a set of strategies and techniques that allow the researcher to obtain the knowledge he was looking for, from the adequate treatment of the collected data.

The data obtained were processed through the statistical program SPSS (Statistical Package for the Social Sciences), this program was used to perform the descriptive statistics of the information obtained, likewise, the elaboration of the data book was carried out through the Excel program.

The results per variable are as follows: influx:

Dependent variable: Increase in tourist

- $\quad 97.63 \%$ of foreign tourists visited the State for more than five nights.

- $58.9 \%$ of the tourists who visited the State went to more than three municipalities.

- The main reason for the trip of tourists who visited Michoacán was for cultural reasons, a portion of $77.4 \%$.

- $99.47 \%$ of tourists would visit the State again on another occasion (Graphic 1). 


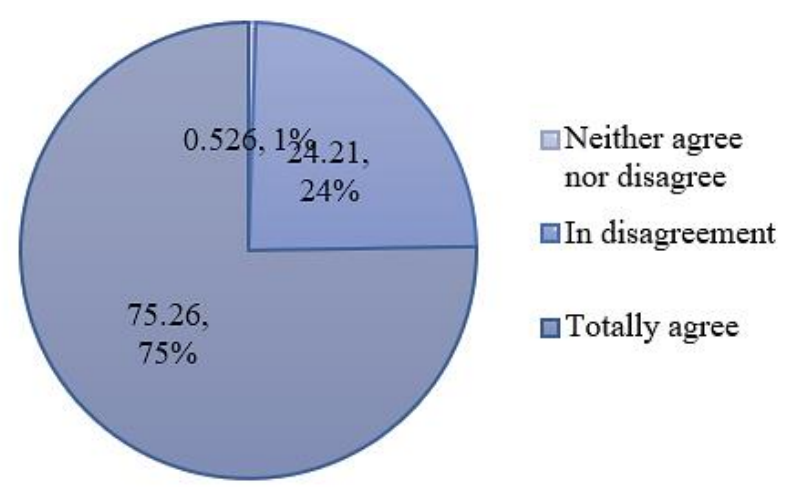

Graphic 1 Percentage of foreign tourists who would visit the state of Michoacán again

Source: Own elaboration in SPSS based on results

\section{Independent Variable 1: Tourist} competitiveness:

- $98.95 \%$ of tourists think that the prices of tourist services are below the prices in other countries.

- $94.2 \%$ of foreign tourists believed that the quality of tourism services offered by the state fully satisfied their needs and expectations (Graphic 2).

- $63.1 \%$ of foreign tourists who visited the State think that advertising tourist services is considered persuasive for their consumption.

- $86.9 \%$ of tourists agreed that the staff of tourism companies in the State is adequately trained to offer quality services, only $7.4 \%$ of tourists think otherwise.

- $48.2 \%$ of tourists thought that the coverage of the telephone lines was efficient.

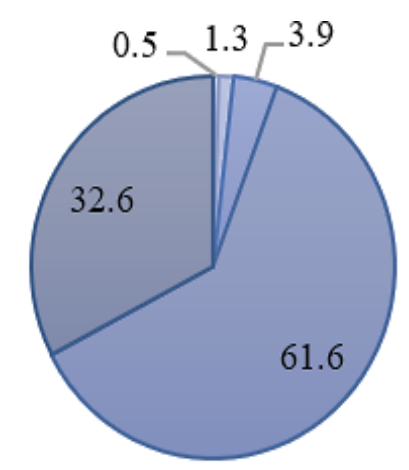

$\square$ Strongly
disagree
$\square$ In disagreement
$\square$ Neither agree
nor disagree
$\square$ Agree

Graphic 2 Quality of tourist services offered by the state of Michoacán

Source: Own elaboration in SPSS based on results

- $74 \%$ of tourists believed that the carts are not in adequate condition 204 (Graphic 3).

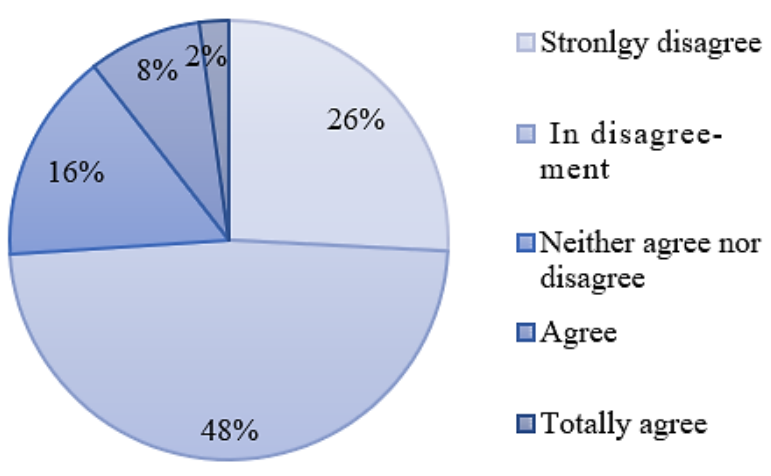

Graphic 3 Road conditions in the state of Michoacán Source: Own elaboration in SPSS based on results

- On the other hand, $86 \%$ of foreign tourists do not agree that the state's means of transport are in adequate conditions to offer the transport service.

Independent Variable 2: Tourism infrastructure:

- $58 \%$ of the tourists thought that the propaganda adequately disseminates the tourist services offered in the State.

- $\quad 86 \%$ of foreign tourists believed that guides provide the necessary information.

- 217 and enough of the services offered (Graphic 4).

- $\quad 84.2 \%$ of tourists believed that state travel agents adequately provide sales, advisory and travel management services.

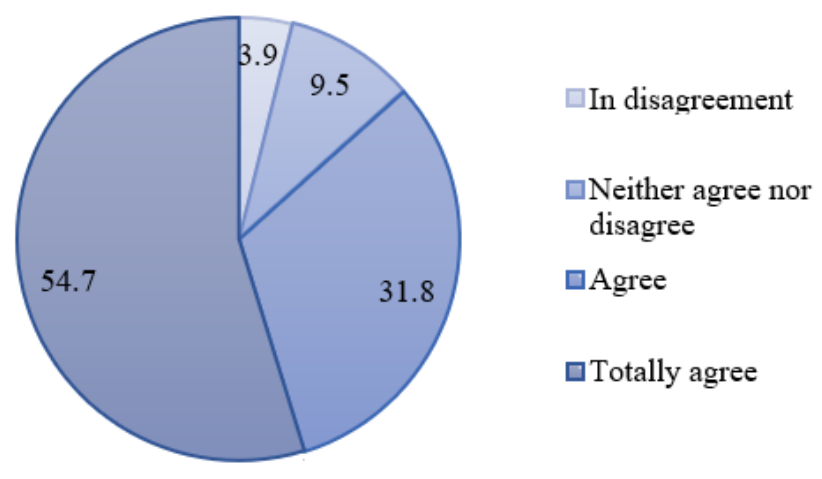

Graphic 4 Tourist guides in the state of Michoacán Source: Own elaboration in SPSS based on results

Independent Variable 3: Diversification of the tourist offer:

- $\quad 53.7 \%$ of foreign tourists visited only one hotel. 
- $\quad 98.7 \%$ of the tourists believed that the hotels in the State adequately meet the needs and fulfilled their expectations.

- Only $46 \%$ of foreign tourists believed that there is a variety of recreation centers in the State.

- $44.5 \%$ of tourists thought that the State recreation centers offer innovative services.

- On the other hand, $82.9 \%$ of foreign tourists believed that there is a great variety of festivals within the State.

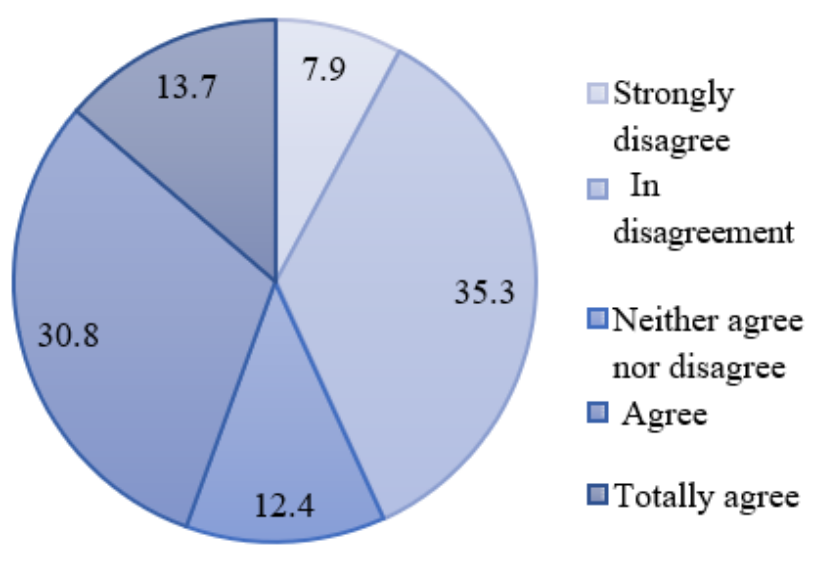

Graphic 5 Innovative services in the recreation centers of the state of Michoacán

Source: Own elaboration in SPSS based on results

\section{Correlation coefficient}

For the analysis of the results, the Pearson correlation coefficient was calculated with the help of the SPSS program, which serves to measure the strength or degree of association between two quantitative variables. The coefficient is defined through the following formula (Ostle, 1980):

$p=\frac{\operatorname{cov}(x, y)}{\sigma x \sigma y}$

$$
-1 \leq \mathrm{p} \geq 1
$$

When $\mathrm{p}$ is positive the relationship is direct between the variables, when it is negative it is inverse, and when $\mathrm{p}$ is equal to 0 the variables are independent. The value of the correlation is equal to 1 or -1 if the covariation is of maximum intensity, and the smaller the intensity of the covariation is, the closer it is to 0 . Furthermore, the index has a positive sign when the covariance is direct and negative when it is inverse.
Table 2 presents the results of Pearson's correlation, in which we can observe that all the variables have a positive correlation with the dependent variable, in addition, the variables are significantly related to each other. To calculate the Pearson correlation in this research, an average of the value of each of the variables was carried out (Annex 3), the result of this average was entered into the SPSS program in which the results presented were obtained.

There is a positive correlation of 0.233 between the variables of increased tourist influx and tourist competitiveness; a positive correlation of 0.118 is shown between the variable of increase in tourist influx and the variable of tourist infrastructure; and there is a positive correlation of 0.138 between the variable of increase in tourist influx and the variable of diversification of the tourist offer.

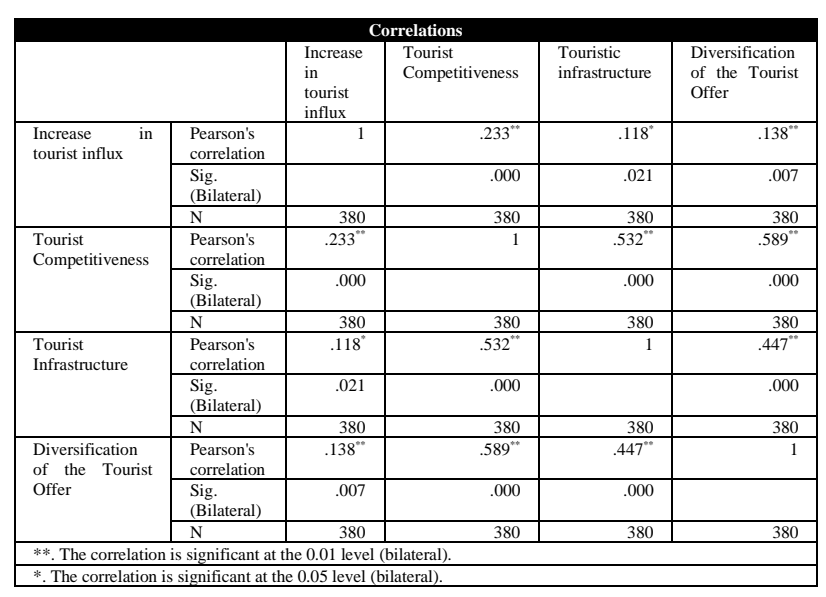

Table 2 Pearson correlations between dependent variable and independent variables

Source: Own elaboration in SPSS based on results

The correlation of the variables is positive and significant, which indicates that the proposed hypothesis is tested: The influx of foreign tourists to Michoacán can be increased by improving tourism competitiveness, increasing investment in tourism infrastructure and diversifying the tourism offer. 


\section{Analysis and discussion of results}

Based on the graphs and tables previously analyzed, it is concluded that the foreign tourists to whom the measurement instrument was applied in this research during the OctoberNovember 2019 period presented a general satisfaction in the tourist services offered by the State, however, the results reflect areas of improvement in terms of communications, road infrastructure and transport, and in terms of the diversification of the tourist offer, since they presented low percentages in terms of satisfaction with respect to these variables . In turn, it has been possible to corroborate that the majority of foreign tourists visited the state during a long stay, visiting more than three municipalities, with this we can conclude that the stay of foreign tourists is much longer than that of tourists Therefore, there is a greater economic spill within the state. Tourism businesses, restaurants, bars and recreation centers obtain greater economic benefits when the number of foreign tourists grows.

The state of Michoacán has great potential to expand and reinforce resources to strengthen the tourism sector and thus attract a greater number of tourists, tourists must be satisfied during and after their visit to the State, because a tourist satisfied, return to the destination or recommend the place you visited. A positive impact on the tourist encourages the tourist influx to grow since it is a promoter of the tourist destination.

Pearson's correlation confirms that there is a significant and positive relationship between the variables, in other words, it states that there is an increase in tourism influence when tourism competitiveness increases, tourism infrastructure improves and tourism offer diversifies, however, The results of this research confirm that there are still areas for improvement that hinder a significant increase in tourist influx, which is why a proposed solution is presented in the next chapter.

\section{Proposal}

This section presents a proposed solution to the problem of the lack of increased tourist influx in the state of Michoacán, a proposal made based on the results obtained and the theoretical framework that supports this research. The proposal consists of the formulation, application and control of a Comprehensive Tourism Planning Model that addresses the variables reviewed in this research, it is worth mentioning that the proposal is directed to government institutions in charge of planning and coordinating tourism plans and programs. in the state of Michoacán (Figure 1).
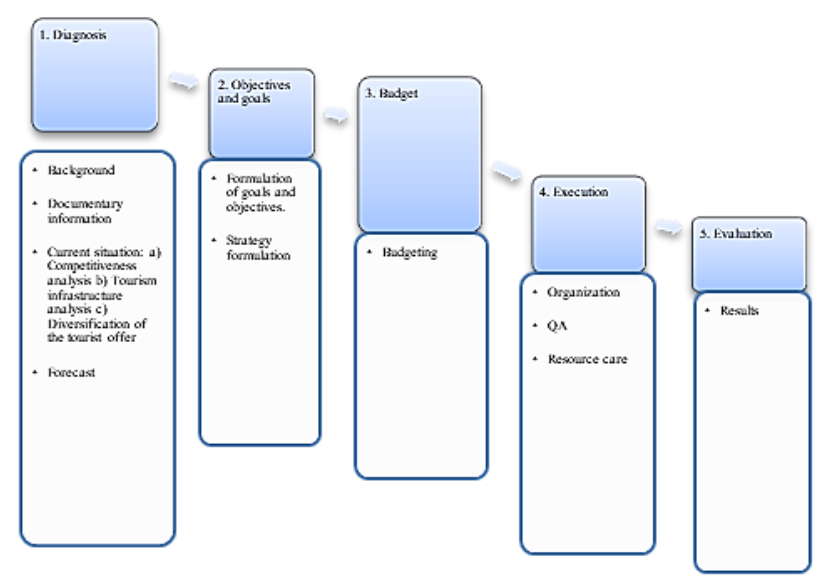

Figure 1 Comprehensive Tourism Planning Model Source: Own elaboration, 2020

As a first step for the formulation of this Comprehensive Tourism Planning Model is the elaboration of a diagnosis (figure 1.2) that includes the study of the documentary information of the site, an analysis of the historical background, an analysis of the current situation of the destination and making a forecast.

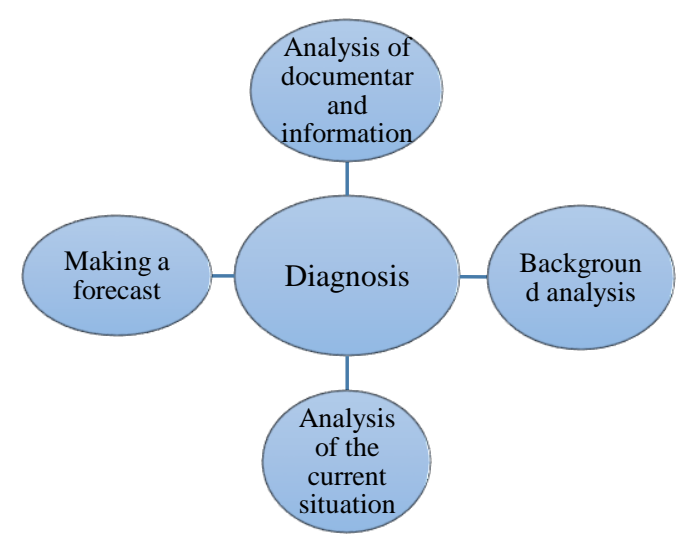

Figure 2 Elements for the elaboration of a diagnosis Source: Own elaboration, 2020 
The elaboration of a diagnosis as the first step of this model helps to understand any situation, the importance of it, how we should act and the possible consequences.

Within the realization of the diagnosis, the analysis of the current situation must include a study of the tourist competitiveness of the destination, which corresponds to the first independent variable of this research. Ritchie \& Crouch $(2000,2003)$ were the first to develop an explanatory model of competitiveness of tourist destinations, which has been improving over the years, mainly through the aggregation of platforms and, most importantly, with the inclusion of the sustainability factor.

Within the analysis of the current situation, a study of the tourist infrastructure should also be carried out, which corresponds to the second independent variable of this research. Tourist infrastructure is understood as the interconnected elements that allow tourists to arrive, stay and enjoy a tourist attraction of their destination.

On the other hand, the diagnosis of the Integral Model of Tourism Planning must include a study of the tourist offer and explain how to achieve its diversification in a tourist destination. The World Tourism Organization (1998) defines the tourist offer as the set of tourist products and services made available to the tourist user in a destination for their enjoyment and consumption. The elements that are considered as tourist offer are:

- Goods and services.

- Elements of the environment (natural, cultural, and historical resources).

- Elements of infrastructure and public facilities.

- Elements of infrastructure and private or state facilities.

- Brand image and price.
The second step of the Model consists of formulating the objectives and goals. Any type of organization must have clearly articulated goals and objectives to channel the efforts of individuals through the organization towards common ends. Goals and objectives also provide the means to allocate resources effectively (Martínez \& Milla, 2012). Once the diagnosis is made and the desired information is available, the goals and strategies must be formulated to achieve the desired objectives.

The third step of the Comprehensive Tourism Planning Model consists of formulating a budget based on the objectives and strategies proposed in the previous section. According to Burbano (2005), the budget is a formal quantitative expression of the objectives that the company administration proposes to achieve in a period with the adoption of the necessary strategies to achieve them, in the same way, this author indicates that it is a programmed estimate, in a systematic way, of the operating conditions and the results to be obtained by an organization in a given period.

Execution is the fourth step of the Comprehensive Tourism Planning Model and consists of applying the plans proposed to achieve the objectives, through a specific budget. In this step the organization of the resources, the monitoring to detect variations and the care of the resources are carried out. Execution is defined as the process in which what is established in the planning is executed, based on the results obtained in the research, it is intended to achieve the proposed objectives (Ander-Egg, 2003). It oversees coordinating people and resources to carry out the proposed plan, it also integrates and carries out the activities according to the proposed strategies.

The evaluation is the fifth and last step of the Model, it consists of knowing the effective, positive or negative impact of a project, it serves to verify the coincidence of the tasks executed with the programmed. Analyze the causes, errors, benefits, and possible areas to improve for better performance. Vedung (1997), believes that evaluation is a process through which a careful retrospective assessment of the merits, importance and value of the application, productivity and results of government interventions is carried out, which is intended to play a role in future situations and practical actions. 


\section{Conclusions}

The research has allowed to know in greater depth the problem of the lack of increase in foreign tourist influx in the state of Michoacán.

During the investigation, it was found that problems such as low tourist competitiveness, lack of investment in tourist infrastructure and little diversification of the tourist offer have arisen in the state, which have caused stagnation in the tourist influx. Through field work, the hypothesis raised was verified and it is concluded that in Michoacán there are several problems that hinder the increase in tourist influx, therefore, a solution proposal is proposed.

This model consists of a series of systematized steps starting from a diagnosis of the current situation of tourism in the State, also from the formulation of plans, strategies and budgets according to the needs of the sector, in addition, this model proposes a set of measures of control to evaluate the model and to be able to carry out a feedback that will allow to work in the possible areas of improvement.

Carrying out systematic and orderly planning in the tourism sector will allow the State to create better strategies and action plans to attract a greater number of foreigners, offer better quality tourism services at competitive prices, improve infrastructure and diversify the tourism offer., and turn the state of Michoacán into a competitive destination worldwide.

\section{References}

Dwyer, L., \& Kim, C. (2003). Destination Competitiveness: Determinants and indicators. Current Issues in Tourism.

Hernández, R., Fernández, C., \& Baptista, P. (1998). Metodología de la Investigación. México: Mc Graw Hill.

Leiper, N. (1979). The Framework of Tourism. Obtenido de https://franciscodosanjos.files.wordpress.com/2 013/12/leiper.pdf
Maldonado, S. (2007). Manual Práctico Para El Diseño De La Escala Likert. Obtenido de Revista Xihmai: http://www.lasallep.edu.mx/xihmai/index.php/x ihmai/article/view/83

Malhotra, N. (2004). Investigación de mercados. México: Pearson.

Martínez, D., \& Milla, A. (2012). Metas Estratégicas. Madrid: Ediciones Diaz de Santos. Osorio, M. (Junio de 2006). La planificación turística. Enfoques y modelos. Obtenido de La planificación turística. Enfoques y modelos: https://www.redalyc.org/pdf/401/40180113.pdf ?sequence $=1 \&$ isAllowed $=\mathrm{y}$

Panosso, A., \& Lohmann, G. (2012). Teoría del Turismo. México: Trillas.

SECTUR. (2018). Secretaría de Turismo. Obtenido de Secretaría de Turismo: https://www.gob.mx/sectur/prensa/alcanzamichoacan-la-mayor-afluencia-en-la-historiade-ferias-de-pueblos-magicos?idiom=es

UNWTO. (1998). The World Tourism Organization. Obtenido de https://media.unwto.org/es/content/entender-elturismo-glosario-basico

Vivanco, M. (2005). Muestreo Estadístico, Diseño y Aplicaciones. Santiago de Chile: Editorial Universitaria. 